\title{
Analisis Permasalahan Sanitasi Pada Desa Kukin Kecamatan Moyo Utara
}

\author{
Iga Maliga ${ }^{1}$, Abdul Hamid ${ }^{2}$ \\ ${ }^{1}$ Program Studi S1 Keperawatan STIKES Griya Husada Sumbawa \\ ${ }^{2}$ Program Studi S1 Kesehatan Masyarakat STIKES Griya Husada Sumbawa \\ Surel: igamali0708kaskus@gmail.com
}

\section{ABSTRAK}

Sanitasi berkaitan langsung dengan kesehatan masyarakat dalam aspek air bersih dan sarana pembuangan sampah. Banyak penyakit yang disebabkan oleh buruknya sanitasi sehingga akses sanitasi layak menjadi salah satu hak asasi manusia yang wajib didapatkan oleh setiap warga masyarakat yang ditetapkan oleh PBB. Faktor air bersih dan sarana pembuangan sampah menjadi hal dasar yang menjadi pusat perhatian dalam penelitian ini. Penelitian ini dilakukan di Desa Kukin, merupakan salah satu desa tertinggal di Kecamatan Moyo Utara Kabupaten Sumbawa. Penelitian ini dilatarbelakangi oleh aspek sanitasi layak yang seharusnya sudah terpenuhi di masyarakat akan tetapi masih ditemukan di lapangan bahwa aspek tersebut belum terpenuhi $100 \%$. Penelitian ini bertujuan untuk menganalisis permasalahan sanitasi terutama pada aspek air bersih dan pembuangan sampah serta pola Buang Air Besar Sembarangan (BABS). Metode penelitian ini dilakukan dengan menggunakan metode kuantitatif dengan pendekatan deskriptif. Sampel dalam penelitian ini berjumlah 223 orang responden yang tersebar pada 5 dusun yang diambil dengan proses random sampling. Berdasarkan hasil penelitian diperoleh 78,3\% responden membiarkan sampahnya ditumpuk begitu saja dan sisanya adalah dibakar sebanyak 21,7\%. Aspek sampah pada penelitian ini masih belum mendapatkan pengelolaan lebih lanjut karena alasan keterbatasan sarana dan prasarana. Terkait dengan aspek air bersih, $76 \%$ sumber air bersih yang digunakan berasa dan $24 \%$ sisanya tidak berwarna dan tidak berasa. Terakhir, terkait dengan aspek Buang Air Besar Sembarangan (BABS) 52\% responden memilih menggunakan septic tank, 40\% responden memilih membuang air besar di got, melakukan BAB di sungai $5 \%$ dan $3 \%$ responden memilih opsi lain-lain.
\end{abstract}

\section{Kata kunci}

Air Bersih, Buang Air Besar Sembarangan

(BABS), Sampah, Sanitasi.

\section{PENDAHULUAN}

Kesehatan lingkungan di daerah
pedesaan masih menjadi aspek yang
diabaikan. Menurut Tanaka ${ }^{[1]}$, pencemaran air di wilayah perkotaan dan pedesaan Indonesia masih menjadi masalah serius. Pada tahun 2006, kerugian ekonomi Indonesia akibat wabah penyakit, kematian balita, dan 
penambahan biaya pengolahan air yang dipicu oleh kondisi sanitasi yang buruk diperkirakan mencapai USD 6,3 miliar. Pemerintah kota yang telah membangun Instalasi Pengolahan Air Limbah (IPAL) tersentralisasi hanya 11 kota diantara 95 kota lainnya. Kota yang telah memiliki IPAL, hanya sebagian rumah tangga yang dapat tersambung langsung dengan IPAL. Dengan demikian, sistem IPAL tersentralisasi hanya mencakup $2 \%$ penduduk Indonesia.

Urgensi penyediaan akses sanitasi yang layak khususnya bagi masyarakat perdesaan baik di Indonesia maupun di negara lainnya kian mendesak. Hal inilah yang memicu PBB menetapkan sanitasi sebagai hak azazi manusia pada tahun 2010 silam. Betapa pentingnya akses sanitasi sehingga tinjauan kesehatan membuktikan bahwa sanitasi yang tidak layak menjadi faktor penyebab penularan berbagai penyakit seperti diare, kolera, disentri, hepatitis A, tifus, polio dan terhambatnya pertumbuhan pada Balita $^{[2]}$. Sanitasi adalah aspek utama yang wajib diperhatikan dalam hal kesehatan masyarakat. Pengertian sanitasi sangat luas. Dari sisi teknis, sanitasi melingkupi tiga unsur, yaitu: air limbah, persampahan, dan drainase lingkungan. Ketiga unsur sanitasi tersebut memiliki kompleksitas tersendiri. Pencapaian target mDGs indonesia kurang menunjukkan kemajuan yang berarti dan berada di bawah capaian negara tetangga, terutama dalam hal sanitasi $^{[3]}$. Menurut Suanta ${ }^{[4]}$, Laporan Program Pembangunan dari United Nation for Development

Programme

(UNDP)

Perserikatan Bangsa-bangsa (PBB) mengenai status pencapaian Tujuan Pembangunan Manusia atau Milenium Development Goals (MDGs) di Indonesia mengalami kemunduran. Pada tahun 2015, MDGs mencanangkan 69 persen penduduk Indonesia dapat mengakses air minum yang layak dan 72,5 persen memperoleh layanan sanitasi yang memadai. Faktanya, hanya 18 persen penduduk yang memiliki akses ke sumber air minum dan sekitar 45 persen mengakses sarana sanitasi yang memadai.

Menurut Puspitawati dan Sulistyarini ${ }^{[5]}$, Sanitasi lingkungan sangat terkait dengan ketersediaaan air bersih, ketersediaan jamban, jenis lantai rumah serta kebersihan peralatan makan pada setiap keluarga. Makin tersedia air bersih untuk kebutuhan sehari-hari, makin kecil risiko anak terkena penyakit kurang gizi. Tingkat kesehatan lingkungan ditentukan oleh berbagai kemungkinan bahwa lingkungan berperan sebagai pembiakan agen hidup, tingkat kesehatan lingkungan yang tidak sehat bisa diukur dengan Penyediaan air bersih yang kurang, Pembuangan air limbah yang tidak memenuhi persyaratan kesehatan, Penyediaan dan pemanfaatan tempat pembungan kotoran serta cara buang kotoran manusia yang tidak sehat, Tidak adanya penyediaan dan pemanfaatan tempat pembuangan sampah rumah tangga yang memenuhi persyaratan kesehatan, Tidak adanya penyediaan sarana pengawasan penyehatan makanan, serta Penyediaan sarana perumahan yang tidak memenuhi persyaratan kesehatan. Hal-hal yang menyangkut sanitasi pertama adalah Ventilasi. Situasi perumahan penduduk dapat diamati melalui perumahan yang berada di daerah pedesaan dan perkotaan. Perumahan yang berpenghuni banyak dan ventilasi yang tidak memenuhi syarat-syarat kesehatan dapat mempermudah dan memungkinkan adanya transisi penyakit dan mempengaruhi kesehatan penghuninya.

Bertambahnya jumlah manusia sebanding dengan kebutuhannya tehadap air. Namun pada saat ini, ketersediaan air secara kuantitas dan kualitas semakin menurun. Oleh karena itu, wilayah perkotaan dan pedesaan terancam mengalami krisis air bersih. Permasalahan tersebut salah satunya diakibatkan oleh masuknya limbah ke badan sungai, danau dan atau air tanah. Sungai merupakan salah satu sumber air yang dapat dimanfaatkan untuk memenuhi kebutuhan hidup manusia dan makhluk hidup lainnya. Bagi manusia sungai dapat digunakan untuk kegiatan domestik, pertanian, dan atau industri. Hal ini menyebabkan permasalahan yang cukup signifikan terhadap sanitasi layak. Rumah tangga dikatakan menggunakan/mempunyai akses air minum layak apabila sumber air minum yang digunakan rumah tangga berasal dari leding, air terlindung (pompa/sumur bor, sumur terlindung, mata air terlindung) dengan jarak 
$>=10 \mathrm{~m}$ dari penampungan kotoran/limbah, dan air hujan. Sementara rumah tangga yang menggunakan air kemasan (bermerk dan isi ulang) dikategorikan sebagai tidak ada akses terhadap air minum layak. Rumah tangga dikatakan menggunakan/mempunyai akses sanitasi (sanitasi layak) apabila rumah tangga menggunakan fasilitas buang air besar (BAB) sendiri dan bersama, kloset leher angsa, dan tangki septik sebagai tempat pembuangan akhir kotoran/tinja (TPAT).

Selain air bersih, sarana pembuangan sampah juga menjadi salah satu faktor sanitasi layak yang dicanangkan oleh pemerintah Indonesia. Sampah adalah suatu benda atau bahan yang sudah tidak digunakan lagi oleh manusia sehingga dibuang. Stigma masyarakat terkait sampah adalah semua sampah itu menjijikkan, kotor, dan lain-lain sehingga harus dibakar atau dibuang sebagaimana mestinya ${ }^{[6]}$. Kebanyakan fakta yang ditemukan bahwa sampah masyarakat di pedesaan masih mengandalkan pembuangan sampah dengan cara dibakar, dikubur atau dbiarkan begitu saja.

Menurut Kementerian Kesehatan Republik Indonesia ${ }^{[2]}$, Sanitasi Total Berbasis Masyarakat (STBM) yang disinergikan dengan upaya kolaboratif seperti terobosan pemimpin daerah, kemitraan lintas sektor dan partisipasi aktif masyarakat, STBM sebagai strategi nasional pembangunan sanitasi perdesaan telah berhasil meningkatkan akses sanitasi $47 \%$ penduduk perdesaan di tahun 2015 serta menurunkan jumlah penduduk perdesaan yang melakukan praktik buang air besar sembarangan (BABS) tiga kali lipat dari rata-rata $0,6 \%$ per tahun (2000-2008) menjadi $1,6 \%$ per tahun sepanjang 2008-2015.

Desa Kukin adalah salah satu desa yang berada di Kecamatan Moyo Utara. Kecamatan Moyo Utara berada di Kabupaten Sumbawa yang masuk dalam salah satu Kabupaten yang masuk dalam kategori 3T. Desa ini masih terbatas dalam proses pengelolaan sampah secara terintegrasi. Menurut Sahil ${ }^{[7]}$, salah satu faktor yang mempengaruhi sistem pengelolaan sampah ialah budaya sikap dan perilaku masyarakat. Hal ini berkaitan dengan masyarakat yang merupakan sumber (produsen) sampah. Selain itu, akses transportasi serta sarana jalan yang masih belum memadai menjadi salah satu faktor penghambat yang menyebabkan proses sanitasi di desa ini masih kurang.

Berdasarkan data BPS Moyo Utara dalam Angka ${ }^{[8]}$, beberapa dampak dari sanitasi yang buruk menyebabkan penyakit diare menjadi salah satu penyakit yang paling dirasakan di Desa Kukin. Selain itu, menurut Puspitawati dan Sulistyarini ${ }^{[5]}$ juga menunjukkan bahwa akses sanitasi yang buruk akan menyebabkan berbagai dampak terhadap ekonomi, sosial dan kesehatan serta gizi balita.

Kondisi demografi Desa Kukin dihuni oleh 414 Kepala Keluarga dengan kategori salah satu desa yang memiliki kepadatan jumlah penduduk. Selain itu, desa ini juga memiliki wilayah yang berada pada pesisir pantai dan melewati saluran drainase. Dengan demikian, penelitian ini dikhususkan untuk menganalisis permasalahan sanitasi layak yang meliputi sanitasi layak, air bersih dan sarana pembuangan sampah di Desa Kukin.

\section{METODE PENELITIAN}

Penelitian ini dilakukan pada bulan Januari - Februari 2019 di Desa Kukin. Desa Kukin meliputi 5 dusun yaitu Kukin A, Kukin B, Ai Bari, Unter Mas dan Bajo. Penelitian ini menggunakan metode deskriptif kuantitatif dengan teknik simple random sampling. Unit analisis dalam penelitian ini adalah ibu atau anak perempuan yang sudah menikah yang ada dalam satu keluarga.

Jumlah sampel dalam penelitian ini adalah $223 \mathrm{KK}$ dengan menggunakan rumus Slovin seperti berikut,

$$
\mathrm{n}=\frac{\mathrm{N}}{\mathrm{N} \cdot \mathrm{d}^{2}+1}
$$

Dimana: $\mathrm{n}$ adalah jumlah sampel

$\mathrm{N}$ adalah jumlah populasi

$\mathrm{d}$ adalah persentase toleransi ketidaktelitian karena kesalahan pengambilan sampel yang masih dapat ditolerir $10 \%(\mathrm{~d}=0,1)$. 
Penelitian ini menggunakan instrumen berupa kuesioner yang berisi pertanyaan tertutup dan pertanyaan terbuka. Isi kuesioner yang telah terisi dianalisis dengan menggunakan software Microsoft Excell dan SPPS for Windows.

\section{HASIL DAN PEMBAHASAN \\ Pola pembuangan sampah}

Berdasarkan hasil penelitian, didapatkan bahwa di Desa Kukin masih terbiasa dengan cara membuang sampah sembarangan.

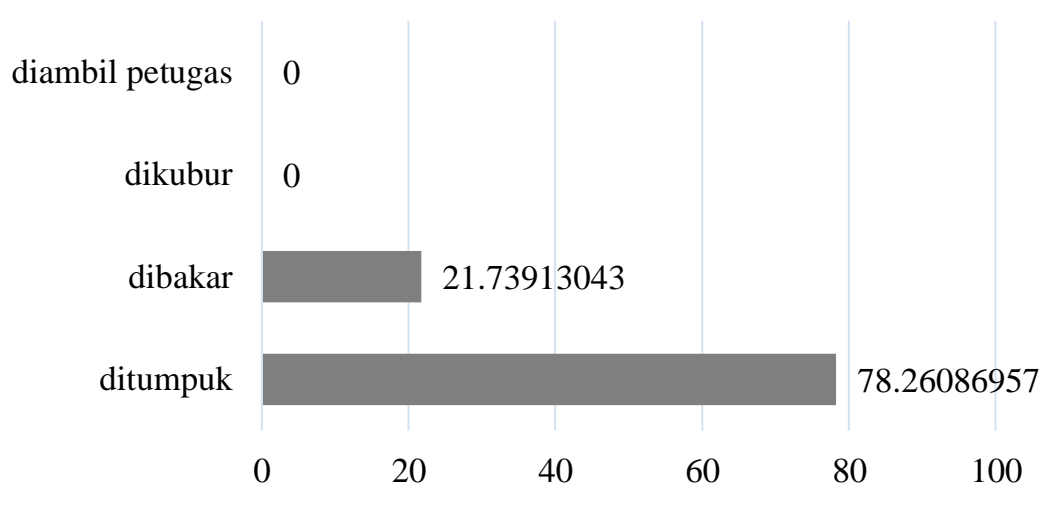

Gambar 1. Cara Membuang Sampah di Desa Kukin

Berdasarkan Gambar 1 diketahui bahwa pola pembuangan sampah dengan cara ditumpuk dibiarkan begitu saja masih menjadi pola yang dominan di Desa Kukin. Selanjutnya adalah dengan cara dibakar denga $21,7 \%$ responden memilih jawaban tersebut. Hal ini disebabkan karena truk pengangkut sampah belum mengakses wilayah ini.

\section{Pola Akses Air Bersih}

Hasil penelitian menunjukkan bahwa mayoritas penduduk desa telah mendapatkan sarana air bersih hanya saja masih ada ditemukan air yang memiliki endapan dan berasa. Jika mengacu pada Permenkes Nomor 32 Tahun 2017 tentang Standar Baku Mutu Kesehatan Lingkungan dan Persyaratan Kesehatan Air untuk Keperluan Higiene Sanitasi, Kolam Renang, Solus Per Aqua, dan Pemandian Umum, maka air untuk sanitasi seharusnya tidak berbau dan berasa. Akan tetapi masih ditemukan sumber air yang berasa.

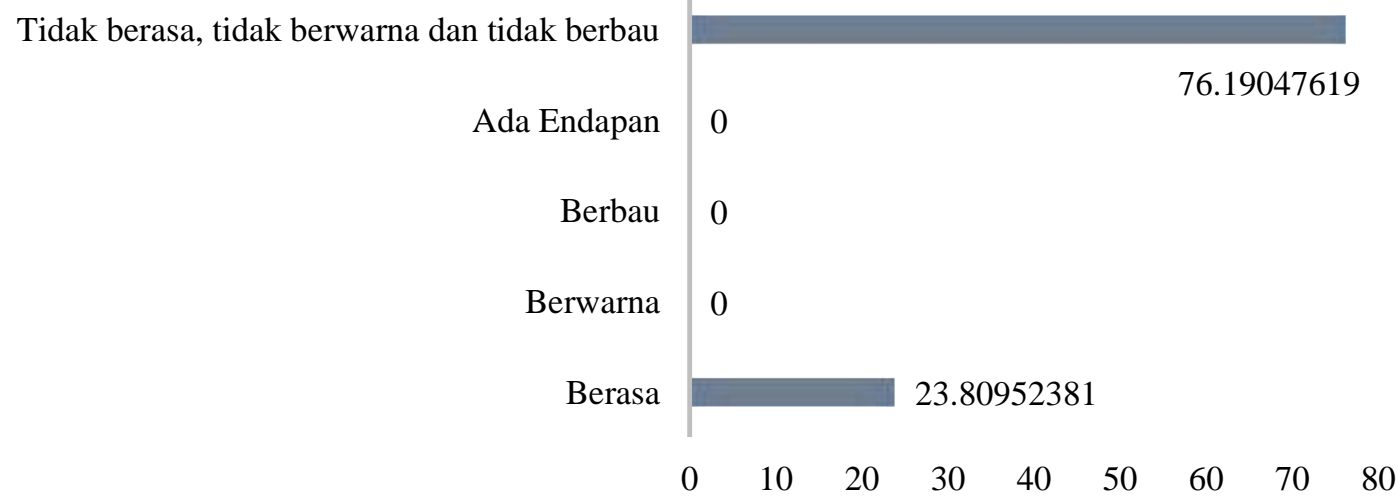

Gambar 2. Keadaan Sumber Air Rumah Tangga di Desa Kukin

Berdasarkan hasil penelitian masih ada sekitar 23,8\% responden yang sumber air rumah tangganya tidak memenuhi air bersih layak karena sumber air tersebut berasa dan 
keruh. Sisanya sudah mampu mendapatkan air yang tidak berasa dan tidak berwarna. Sedangkan pada indikator air layak minum yang diperoleh diperoleh dengan menggunakan rumus berikut.

$\begin{gathered}\text { Banyaknya rumah tangga yang } \\ \begin{array}{c}\text { menggunakan sumber air minum dari } \\ \text { leding, air terlindung dengan jarak } \\ >=10 \text { dari penampungan kotoran, } \\ \text { Layak air hujan }\end{array}\end{gathered}=\frac{\text { Banyaknya rumah tangga }}{\text { Layak }} \times 100 \%$

Berdasarkan hasil penelitian, diketahui ada $87,5 \%$ rumah yang telah mendapatkan akses air minum layak. Layak yang dimaksud dalam kategori ini adalah sumber air terlindungi dengan jarak sama dengan atau lebih dari $10 \mathrm{~m}$ dari penampungan kotoran dan air hujan.

\section{Pola Buang Air Besar Sembarangan (BABS)}

Praktek buang air besar sembarangan diartikan menjadi buang air besar sembarang tempat dan membiarkan tinjanya pada tempat terbuka $^{[9]}$. Berdasarkan hasil penelitian masih ditemukan limbah tinja yang dihasilkan oleh masyarakat di desa tersebut yang dibuang di tempat selain septic tank. Hal ini menunjukkan masih ada pola yang salah dalam sanitasi dan ini akan berdampak negatif pada kesehatan.

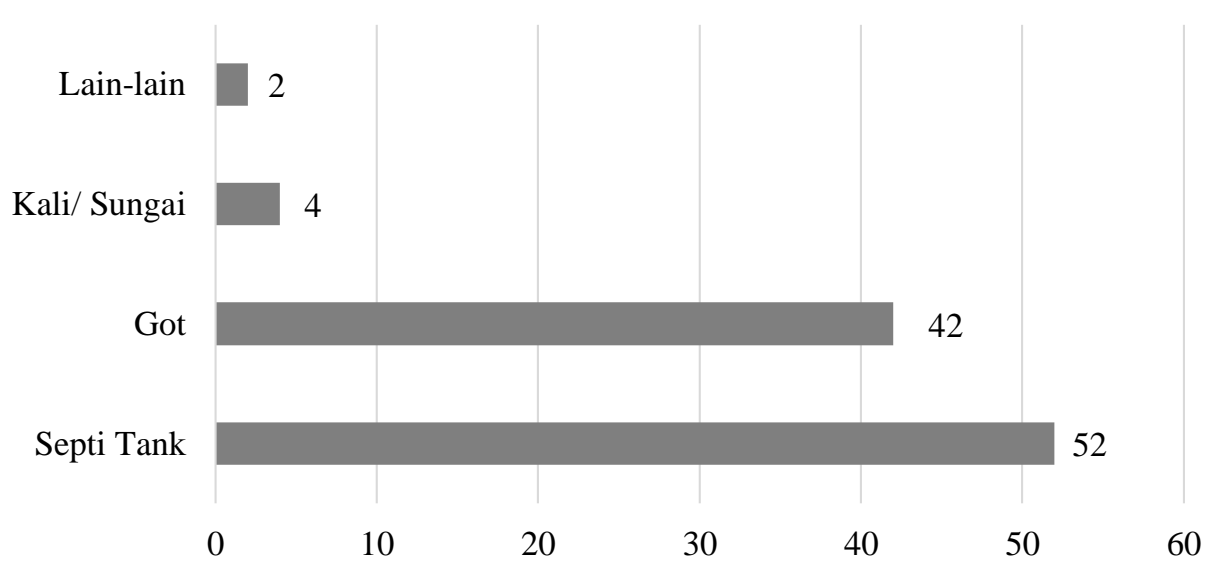

Gambar 3. Pola Pembuangan Limbah Tinja Masyarakat

Sanitasi lingkungan pada hakekatnya adalah suatu kondisi atau keadaan lingkungan yang optimum sehingga berpengaruh positif terhadap terwujudnya status kesehatan yang optimum pula. Ruang lingkup kesehatan lingkungan tersebut antara lain: perumahan, pembuangan kotoran manusia (tinja), penyediaan air bersih, pembuangan sampah, pembuangan air kotor (air limbah), rumah hewan ternak (kandang), dan sebagainya ${ }^{[5]}$.

Menurut Data BPS tahun 2018, Desa Kukin memiliki luas wilayah $11 \mathrm{~km}^{2}$ menempati urutan luas wilayah terbesar keempat dari 6 desa yang ada di Kecamatan Moyo Utara. Kepadatan penduduk di Desa Kukin sebesar 117 jiwa $/ \mathrm{km}^{2}$. Hal ini menunjukkan bahwa desa ini memiliki jumlah penduduk yang cukup padat. Berdasarkan hasil penelitian, untuk kepemilikan jamban, yang memiliki jamban pribadi sebanyak 185 responden atau sebanyak $82,95 \%$ dan sisanya yang masih tidak memiliki jamban.

Desa Kukin merupakan salah satu desa di Kecamatan Moyo Utara yang belum dijangkau oleh truck sampah pengangkutan sampah secara rutin yang dikoordinasikan oleh instansi pemerintah terkait. Hal ini menjadi salah satu faktor penyebab terjadinya sanitasi buruk di desa tersebut. Berdasarkan 3 aspek penentu sanitasi layak yaitu pola pembuangan sampah, akses air bersih dan pola buang air besar sembarangan.

Menurut Ashidiqy ${ }^{[10]}$, ketersediaan sarana menjadi salah satu faktor yang menyebabkan perilaku masyarakat yang masih membuang sampah sembarangan. Hal ini sejalan dengan fakta yang didapatkan di lapangan bahwa masyarakat di Desa Kukin masih mengandalkan cara ditumpuk, dibiarkan saja sebesar 78,3\% dan dibakar 
sebanyak 21.7\%. Pengamatan di lapangan juga membuktikan bahwa proses pengelolaan sampah masih belum dilakukan dan responden menyatakan bahwa selain faktor ketersediaan sarana pengangkutan sampah, faktor pengetahuan juga membuat responden belum mampu melakukan pengelolaan sampah secara mandiri. Menurut Setyowati dan Mulasari ${ }^{[11]}$ menyatakan bahwa faktor pengetahuan juga turut berkontribusi dalam buruknya pola pembuangan sampah rumah tangga.

Pola pembuangan sampah yang tidak tepat sangat berpengaruh terhadap akses sanitasi layak. Hal ini disebabkan karena sampah yang menumpuk ataupun dibakar akan menjadi driving factor terhadap berbagai macam vektor penyakit. Tambuwun ${ }^{[12]}$ menyatakan bahwa sanitasi lingkungan berpengaruh terhadap penyakit diare.

Indikator selanjutnya dalam akses sanitasi layak ini adalah pola akses air bersih. Menurut Unicef Indonesia (2012), sanitasi dan perilaku kebersihan yang buruk serta air minum yang tidak aman berkontribusi terhadap 88 persen kematian anak akibat diare di seluruh dunia. Kondisi geografis Desa Kukin yang berdekatan dengan pesisir pantai menyebabkan akses air bersih agak sulit didapatkan.

Berdasarkan hasil penelitian masih ada sekitar 23,8\% responden yang sumber air rumah tangganya tidak memenuhi air bersih layak. Berdasarkan temuan di lapangan, air yang dimiliki oleh warga berasal dari sumur gali. Air sumur tersebut menjadi sumber air utama yang digunakan untuk kebutuhan sehari-hari. Air baku tersebut masih ditemukan dalam kondisi berasa dan terkadang keruh. Berdasarkan kondisi air tersebut dapat dikatakan tidak memenuhi syarat sesuai standar mutu air yang terkandung dalam Peraturan Menteri Kesehatan No. 416 Tahun 1990 tentang syarat-syarat dan pengawasan kualitas air.

Jarak sumur galian dengan saluran pembuangan air limbah (SPAL) bekas mandi maupun cucian memiliki jarak kurang dari 10 m. Menurut Awaludin ${ }^{[13]}$, di daerah pedesaan pencemaran air umumnya disebabkan oleh limbah rumah tangga secara sembarangan, pertanian, dan peternakan. Air limbah rumah tangga yang dibuang tanpa diolah terlebih dahulu melalui selokan di sekitar rumah yang langsung menuju sungai. Sebagian besar selokan tempat dibuangnya limbah tidak ditutup. Menurut Maliga ${ }^{[14]}$, limbah cair domestik yang tidak diolah secara langsung dapat menyebabkan permasalahan yang mendasar pada ketersediaan dan kemurnian air bersih. Dengan demikian, untuk meningkatkan kualitas air agar menjadi lebih layak harus diperhatikan akses sanitasinya.

Aspek yang terakhir yang dibahas dalam penelitian ini adalah Pola Buang Air Besar Sembarangan (BABS). Salah satu program Kementerian Kesehatan Republik Indonesia, yaitu meningkatkan sanitasi layak $100 \%$, salah satunya menghentikan kebiasaan masyarakat Indonesia dalam BABS. Kebanyakan kebiasaan BABS ini masih ditemukan di wilayah pedesaan. WHO/UNICEF 2014 mencatat 55 juta penduduk di Indonesia masih memiliki perilaku BAB sembarangan. Akibatnya, setiap tahun lebih dari 370 balita Indonesia meninggal akibat perilaku buruk $\mathrm{BAB}$ sembarangan.

Menurut Suanta ${ }^{[4]}$, Berdasarkan hasil Survei Demografi dan Kesehatan Indonesia (SDKI) tahun 2012, delapan belas persen anak yang berasal dari rumah tangga yang memiliki sumber air minum tidak layak (nonimproved source) menderita diare dibandingkan dengan 14 persen anak yang tinggal dalam rumah tangga yang memiliki sumber air minum layak (improved source). Selain itu, prevalensi diare dari anak yang tinggal dalam rumah tangga yang tidak mempunyai fasilitas toilet dan mereka yang tinggal dalam rumah tangga yang memiliki toilet tanpa tangki septik, lebih rendah dibandingkan dengan anak yang tinggal dalam rumah dengan fasilitas toilet jenis lain. Hal ini menunjukkan pola BABS juga dapat meningkatkan risiko terkena diare pada anak.

Seharusnya saat ini sudah tidak ada lagi masyarakat yang melakukan BABS akan tetapi di lapangan masih ditemukan responden melakukan BAB di tempat terbuka. Ada sekitar $42 \%$ responden yang masih BABS di got dan $4 \%$ melakukannya di Sungai. Hal ini 
ketika ditelusuri lebih jauh bahwa ini sudah menjadi kebiasaan dan terjadi karena akses masyarakat yang bermukim di ladang tidak memiliki WC layak sehingga proses BABS tidak terhindarkan.

\section{KESIMPULAN}

a. Pola pembuangan sampah dengan cara ditumpuk dan dibiarkan begitu saja masih mendominasi sebesar 78,3\% dan sisanya adalah dibakar sebanyak $21.7 \%$. Hal ini disebabkan karena keterbatasan sarana pengangkutan sampah.

b. Sekitar $24 \%$ responden yang sumber air rumah tangganya tidak memenuhi air bersih layak karena sumber air masih berasa dan keruh.

c. Ada sekitar $42 \%$ responden yang masih BABS di got dan 4\% melakukannya di Sungai serta sisanya sudah melakukan $\mathrm{BAB}$ menggunakan WC yang penampungannya menggunakan septic tank.

\section{REFERENSI}

[1] Tanaka, N., 2015, Teknologi Tepat Guna \& Dunia Alternatif, Jakarta, Gramedia.

[2] Kementerian Kesehatan Republik Indonesia, 2016, Menuju 100\% Akses Sanitasi Indonesia 2019. Tersedia online di http://www.depkes.go.id/pdf.php?id=1 6060100003.

[3] Adhi, E.T., 2009, Pelayanan Sanitasi Buruk: Akar dari Kemiskinan. Jurnal Analisis Sosial, 14 (2).

[4] Suanta, M., 2016, Pengaruh Sanitasi Lingkungan Tempat Tinggal dan Karakteristik Sosial Ekonomi Rumah Tangga Terhadap Terjadinya Diare Pada Balita di NTT (Analisis Lanjut Data Susenas 2012). Jurnal Bumi Lestari, 16 (2).

[5] Puspitawati, N., Sulistyarini, T., 2013, Sanitasi Lingkungan Yang Tidak Baik Mempengaruhi Status Gizi Pada Balita Di Wilayah RW VI Kelurahan Bangsal. Jurnal STIKES. 6 (1).

[6] Mulasari, S. A., 2012, Hubungan Tingkat Pengetahuan Dan Sikap Terhadap Perilaku Masyarakat Dalam Mengelola Sampah Di Dusun Padukuhan Desa
Sidokarto Kecamatan Godean Kabupaten Sleman Yogyakarta, Jurnal Kesmas, 6 (3), 204-211.

[7] Sahil, J., Al Muhdar, M. H. I., Rohman., 2016, Sistem Pengelolaan dan Upaya Penanggulangan Sampah di Kelurahan DufaDufa Kota Ternate. Jurnal Bioedukasi 4 (2).

[8] Badan Pusat Statistik, 2018, Kecamatan Moyo Utara Dalam Angka, Tersedia online di https://sumbawakab.bps.go.id/ publication/2018/09/26/1eab4b96400954 b284cac0da/kecamatan-moyo-utaradalam-angka-2018.html.

[9] Triyono, A., 2014, Faktor-Faktor yang Berhubungan dengan Perilaku Buang Air Besar Masyarakat Nelayan di Kampung Garapan Desa Tanjung Pasir Kabupaten Tangerang Propinsi Banten. Forum Ilmiah, 11(3).

${ }^{[10]}$ Ashidiqy, M. R., 2009, Analisis FaktorFaktor Yang Berhubungan Dengan Perilaku Masyarakat Dalam Membuang Sampah Rumah Tangga, Skripsi, Jurusan Ilmu Kesehatan Masyarakat Universitas Negeri Semarang.

[11] Setyowati, R., Mulasari, S.A., 2013, Pengetahuan dan perilaku ibu rumah tangga dalam pengelolaan sampah plastik. Kesmas: National Public Health Journal, 7(12), 562-566.

[12] Tambuwun, F., Yudi, A., dan Silolonga, I. W., 2015, Hubungan Sanitasi Lingkungan dengan Kejadian Diare Pada Anak Usia Sekolah di Wilayah Kerja Puskesmas Bahu Manado. e-Journal keperawatan (e-Kp). 3(2).

[13] Awaludin, F. F., 2015, Permasalahan Pencemaran dan Penyediaan Air Bersih di Perkotaan dan Pedesaan. Tersedia online di https://www.researchgate.net /publication/287595699.

${ }^{[14]}$ Maliga, I., 2017, Pengendalian Pencemaran Air Limbah Domestik Menggunakan Constructed Wetlands Teknik Surface Flow (SF), Jurnal Kesahatan dan Sains. 